\title{
OPTIMALISASI PENGATURAN TEGANGAN DI JARINGAN LISTRIK DENGAN MENGGUNAKAN GENETIK ALGORITMA
}

\author{
Zulfahri $^{1}$, Abrar Tanjung ${ }^{2}$, Monice ${ }^{3}$ \\ Program Studi Teknik Elektro, Fakultas Teknik, Universitas Lancang Kuning \\ Jl. Yos Sudarso km. 8 Rumbai, Pekanbaru, Telp. (0761) 52324 \\ Email : ${ }^{1}$ zulfahri@unilak.ac.id , ${ }^{2}$ abrar@unilak.ac.id , ${ }^{3}$ monice@unilak.ac.id
}

\begin{abstract}
ABSTRAK
Ketika beban reaktif induktif meningkat, maka menyebabkan penurunan tegangan, meningkatkan kerugian daya dalam sistem, meenurunkan faktor daya dan mengurangi kapasitas daya serta menurunnya kapasitas pendistribusian daya listrik. Untuk mengurangi beban reaktif induktif, diperlukan sumber daya reaktif kapasitif, yaitu pemasangan kapasitor dengan ukuran optimal dan penempatan yang tepat.

Paper ini memaparkan penggunaan algoritma genetika untuk mengatur optimasi pengaturan tegangan dalam sistem. Melalui aliran daya Newton Rapshon dalam hal pengaturan tegangan dan meminimalkan kerugian daya. Meskipun metode kontrol tegangan yang berbeda dapat digunakan, teori ini berfokus pada bank kapasitor (kapasitor shunt) sebagai parameter variabel. Metode ini diterapkan pada sistem bus standar IEEE 30 untuk memverifikasi kemampuan dan kapabilitasnya.

Dari percobaan dapat dilihat bahwa pendekatan algoritma genetika berhasil menghasilkan kapasitor shunt sebesar 21,9 KVar. diporeleh tegangan tertinggi 1.082 pu dan terendah 0.859 pu dan pengurangan nilai sebesar 2712 KVA. Serta penghemat daya listrik dapat dilakukan sebesar $11.9313 \%$. Total ukuran kapasitor dapat dikurangi dari kondisi awal 23,3 Mvar pada Genetika algoritma dapat diperoleh pengurangan menjadi 21,9 Mvar, sehingga sistem dapat menghemat 1,4 Mvar.
\end{abstract}

Kata Kunci: Peletakan Kapasitor, Tegangan, Algoritma Genetika.

\section{ABSTRACT}

When the inductive reactive load increases, it causes a decrease in voltage, increases power loss in the system, decreases power factors and reduces power capacity and decreases the distribution capacity of electricity. To reduce inductive reactive load, capacitive reactive resources are required, namely the installation of capacitors with optimal size and proper placement.

This paper describes the use of genetic algorithms to adjust the optimization of voltage regulation in the system. Through the Newton Rapshon power flow in terms of voltage regulation and minimizing power losses. Although different voltage control methods can be used, this theory focuses on the capacitor bank (shunt capacitor) as a variable parameter. This method is applied to the IEEE 30 standard bus system to verify its capabilities and capabilities.

From the experiment, it can be seen that the genetic algorithm approach has succeeded in producing a shunt capacitor of 21.9 KVar. the highest voltage was 1,082 pu and the lowest was $0.859 \mathrm{pu}$ and the value reduction was $2712 \mathrm{KVA}$. As well as electrical power savings can be made of $11.9313 \%$. The total capacitor size can be reduced from the initial condition of 23.3 Mvar in the Genetics algorithm to be reduced to 21.9 Mvar, so the system can save 1.4 Mvar.

Keywords: Capacitor Placement, Voltage, Genetic Algorithm.

\section{PENDAHULUAN}

Daya reaktif sudah lama dikenal sebagai faktor yang penting di dalam desain dan pengoperasian sistem tenaga listrik. Secara umum, diketahui bahwa daya reaktif disebabkan oleh jaringan sistem yang tersebar, terutama merupakan komponen reaktif. Penyaluran daya aktif menghasilkan perbedaan di sudut fase antara tegangan di sisi pengiriman dan tegangan di sisi penerimaan, sementara pendistribusi daya reaktif menghasilkan perbedaan magnitude dari tegangan tersebut.

Tingkat pengaturan tegangan sangat tergantung dari pengaturan produksi, penyaluran dan aliran reaktif pada seluruh level sistem. Secara normal ada beberapa metode pengaturan tegangan ,seperti trafo tap-changer, booster transformer, injeksi daya reaktif dan sebagainya (Zainal, 2009).

Salah satu yang membuat ketidakstabilan tegangan, akibat berubahan kondisi beban sehingga terjadi penurunan dan kenaikan tegangan. Untuk menjaga 
kestabilan tersebut diperlukan kompensasi daya reaktif, dengan dilakukannya pemasangan peralatan kapasitor shunt , diharapkan dapat mengurangi drop tegangan yang terjadi sehingga rugi-rugi daya bisa dikurangi.( Arlenny, 2019).

Pemasangan kapasitor shunt adalah cara untuk mengurangi kehilangan daya saluran sekaligus meningkatkan profil tegangan. Namun penempatan kapasitor dengan kapasitas yang tidak optimal dapat menyebabkan peningkatan profil tegangan pada bus tertentu yang melebihi batas yang diizinkan, sehingga dapat mengakibatkan kerusakan pada beban-beban listrik.( Christopher, 2019 ), selain itu, permintaan pasokan listrik reaktif semakin meningkat dikerenakan peningkatan beban bersifat induktif, Beban induktif adalah beban yang banyak menggunakan motor-motor listrik .

Yusmartato (2017) Penelitian tentang kapasitor yang bekerja sebagai pembangkit daya reaktif dan mengurangi jumlah daya reaktif serta jumlah total daya yang dihasilkan oleh bagian utilitas.

Dalam tulisan ini pengaturan tegangan menggunakan daya reaktif atau kapasitor shunt, sebagai unsur utama kontrol tegangan. Kapasitor shunt banyak digunakan sebagai perbaikan deviasi tegangan, pengganti kerugian daya reaktif serta meningkatkan kestabilan tegangan pada sistem tenaga listrik.

Permasalahan umum peletakan kapasitor yaitu penentuan lokasi dan ukuran kapasitor untuk dialokasikan dalam suatu sistem transmisi atau distribusi tenaga listrik, parameter-parameter seperti control setting, biaya-biaya kapasitor, batasan tegangan dan variasi beban, semuanya diperlukan dan dipertimbangkan dengan seksama, sehingga permasalahan menjadi sangat rumit. Untuk menyelesaikan permasalahan tersebut perlu digunakan suatu metode perhitungan untuk menentukan lokasi peletakan dan ukuran kapasitor sehingga diperoleh harga yang optimum.

Salah satu teknik komputasi untuk menyelesaikan permasalahan optimisasi adalah Algoritma Genetika . Algoritma Genetika optimisasi berbasis kecerdasan buatan yang terinspirasi pencarian yang berbasis pada mekanisme seleksi alam dan genetika. kemampuan Algoritma Genetika dalam mengenal pola dan mengingat, mampu menyelesaikan masalah posisi dan ukuran kapasitor shunt dalam sistem kelistrikan dengan hasil mencapai nilai optimal.

\section{METODE PENELITIAN}

\subsection{Gambaran Umum}

Tujuan Penelitian ini menyelesaikan permasalahan Optimalisasi pengaturan tegangan di Jaringan Listrik melalui peletakan (placement) kapasitor yang meliputi penentuan lokasi dan ukuran kapasitor yang akan digunakan data system standar IEEE 30 bus. Ini biasanya ditunjukkan pada Gambar 1. Alur data dan bagan analisis diperlihatkan dalam Gambar 1

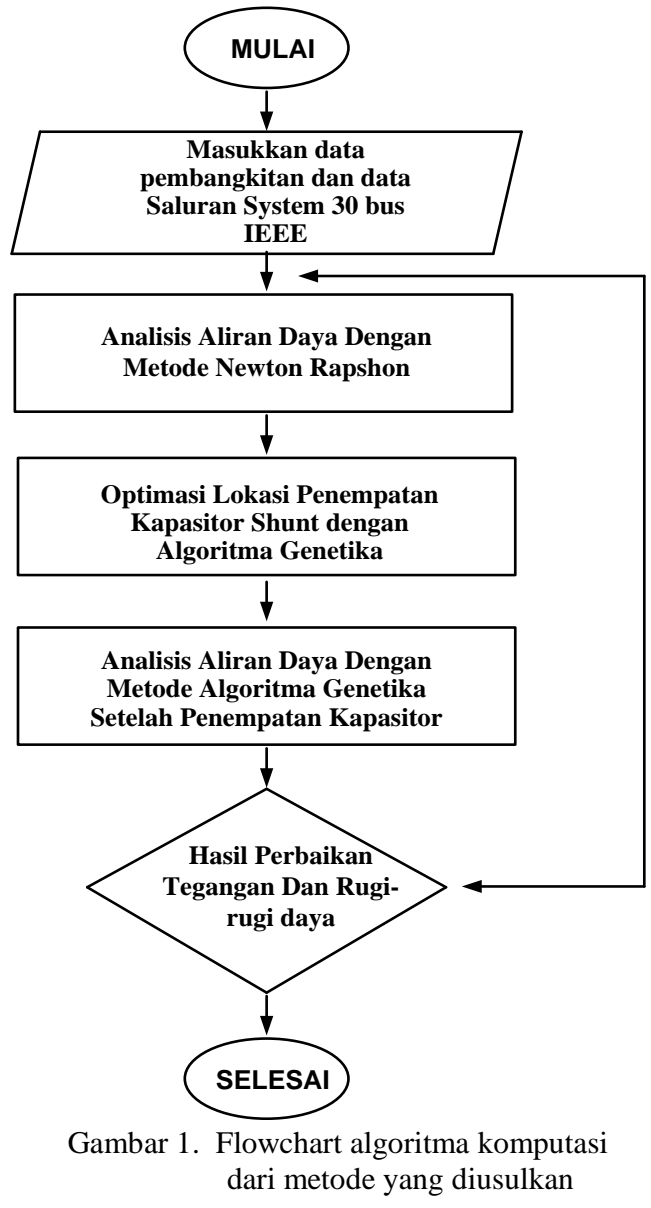

\subsection{Aliran daya reaktif}

Komponen resistif, seluruh peralatan penghubung energi, termasuk trafo dan peralatan konverter energi (seperti motor dan generator), beroperasi sesuai dengan basis kapasitas energi yang disimpan dan yang dilepaskan. Daya rata-rata dalam rangkaian tersebut sebagai daya aktif dan daya yang disuplay energi yang tersimpan dalam elemen reaktif tersebut sebagai daya aktif.

$$
\begin{aligned}
& \mathrm{P}=\mathrm{V} . \mathrm{I} \cos \theta . \\
& \mathrm{Q}=\mathrm{V} . \mathrm{I} \sin \theta .
\end{aligned}
$$

Pada kedua persamaaan, V dan I adalah nilai rms dari tegangan terminal dan arus, dan $\theta$ adalah sudut phasa antara arus yang tertinggal terhadap tegangan

P dan Q berada pada dimensi yang sama, yaitu watt, namun untuk menekan bahwa $\mathrm{Q}$ adalah daya reaktif maka $Q$ dihitung dalam unit volt ampere reaktif (VAR). Dengan mengasumsi $\mathrm{V}, \mathrm{V} \cos \theta$ dan $\mathrm{V} \sin \theta$, seperti yang ditunjukkan gambar 2 , masingmasing dikalikan dengan I, nilai arus rms. Ketika komponen tegangan $\mathrm{V} \cos \theta$ dan $\mathrm{V} \sin \theta$ dikalikan $\theta$ akan berubah menjadi V.I, P, dan Q. Daya yang dinyatakan dalam bilangan kompleks dilambangkan dengan $\mathrm{S}$ terdiri dari komponen $\mathrm{P}$ dan $\mathrm{Q}$ yaitu :

$$
\begin{aligned}
\mathrm{S} & =\mathrm{P}+\mathrm{jQ} \\
& =\mathrm{V} . \mathrm{I} \cos \theta+\mathrm{j} \mathrm{V} . \mathrm{I} \sin \theta
\end{aligned}
$$


$=\mathrm{V} \cdot \mathrm{I}(\cos \theta+\sin \theta)$ leh

Dengan menggunakan idensitas Euler dipero-

$$
\mathrm{S}=\text { V.I } \angle \theta
$$

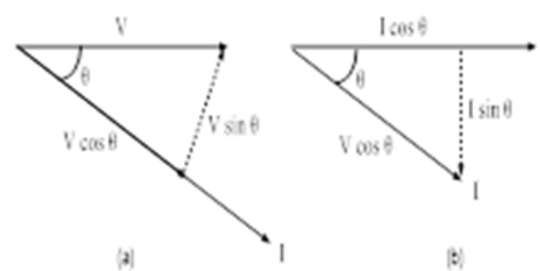

Gambar 2. Diagram fasor I lagging terhadap V

Arus conjugate didefinisikan dengan menambah tanda $(*)$.

$$
\begin{aligned}
& \mathrm{I}^{*}=|I| \angle \theta \\
& \mathrm{S}=\mathrm{V} . \mathrm{I}^{*}
\end{aligned}
$$

Daya reaktif sebesar $\mathrm{I}^{2} \mathrm{X}_{\mathrm{L}}$ (dengan tanda positif) diberikan pada induktansi atau induktansi menyerap daya reaktif. Arus I terbelakang (lagging) $90^{\circ}$ terhadap tegangan V. Gambar 3. single line sebelah kiri memperlihatkan arus dengan sudut $-90^{\circ}$ yang bearti lagging. Sementara sebelah kanan memperlihatkan diagram fasor berlawanan arah dengan arah putaran jam, memperlihatkan I terbelakang terhadap V.
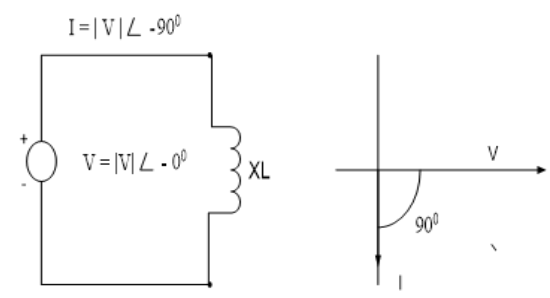

Gambar 3. Diagram fasor aliran daya reaktif I lagging $90^{\circ}$ terhadap tegangan $\mathrm{V}$

Gambar 4. single line sebelah kiri memperlihatkan arus dengan sudut fase $90^{\circ}$ berarti leading. Sementara sebelah kanan memperlihatkan diagram fasor berlawanan arah putaran jarum jam memperlihatkan I mendahului terhadap V.
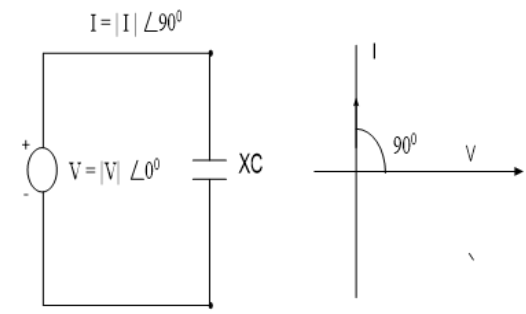

Gambar 4. Diagram fasor aliran daya reaktif I leading $90^{\circ}$ terhadap tegangan $\mathrm{V}$

\subsection{Penerapan metode Newton Raphson.}

Dalam metode ini, persamaan aliran daya diformulasikan dalam bentuk polar. Arus yang masuk ke I bus dapat ditulis dengan persamaan berikut :

$\mathrm{I}_{1}=\sum_{\mathrm{j}}^{\mathrm{n}}\left|\mathrm{Y}_{\mathrm{ij}}\right|\left|\mathrm{V}_{\mathrm{j}}\right|\left\llcorner\theta_{\mathrm{ij}}+\delta_{\mathrm{j}}\right.$

Daya kompleks pada bus i adalah :

$P_{i}^{\wedge}-j Q_{i}^{\wedge}=V_{i}^{*} I_{1}$

Dari persamaan (1) dan (2) didapat persamaan :

$P_{1}-j Q_{i}=\left|V_{i}\right|-\delta_{1} \sum_{j}^{n}\left|Y_{i j}\right|\left|V_{j}\right|\left\llcorner\theta_{i j}+\delta_{j}\right.$

Atau kalau dipisahkan bagian real dan imajiner

$P_{i}=\sum_{j=1}^{n}\left|V_{i}\right|\left|V_{j}\right|\left|Y_{i j}\right| \cos \left(\theta_{i j}-\left(8_{i j} .6\right) \delta_{j}\right)$

Dan

$\mathrm{Q}_{\mathrm{i}}=\sum_{\mathrm{j}=1}^{\mathrm{n}}\left|\mathrm{V}_{\mathrm{i}}\right|\left|\mathrm{V}_{\mathrm{j}}\right|\left|\mathrm{Y}_{\mathrm{ij}}\right| \sin \left(\theta_{\mathrm{ij}}-\delta_{\mathrm{i}}-\delta_{\mathrm{j}}\right)$

Persamaan (10) dan (11) pembentuk persamaan aljabar nonlinear dengan variabel sendiri. Ukuran setiap variabel dinyatakan dalam unit per unit, dan sudut fasa dinyatakan dalam unit radial. Metode ini menggunakan deret Tailor sebagai dasar untuk menghitung iterasinya menggunakan jacabian.

$$
\left[\begin{array}{ll}
\Delta & P \\
\Delta & Q
\end{array}\right]=\left[\begin{array}{ll}
J_{1} & J_{2} \\
J_{3} & J_{4}
\end{array}\right]\left[\begin{array}{cc}
\Delta & \delta \\
\Delta & |V|
\end{array}\right]
$$

Banyaknya elemen Persamaan Jacabian (12) didefinisikan $(2 n-2-m) \times(2 n-2-m)$ dengan $n$ adalah jumlah bus dalam sistem, sementara $m$ adalah jumlah bus yang dikendalikan tegangan pada sistem.

Harga dari $\Delta \operatorname{Pi}^{\wedge}((\mathrm{k}))$ dan $\Delta \mathrm{Qi}^{\wedge}((\mathrm{k}))$ berbeda antara perkiraan nilai terencana dan perkiraan estimasi biaya, ini disebut kapasitas yang tersisa yang disediakan oleh perhitungan baru untuk sudut fasa dan tegangan bus adalah :

$\delta_{i}^{(k+1)}=V_{i}^{(k)}+\Delta \delta_{i}^{k}$

$\mathrm{Vi}^{\wedge}((\mathrm{k}+1))=\left|\mathrm{Vi}^{\wedge}((\mathrm{k}))\right|+\Delta\left|\mathrm{Vi}^{\wedge}((\mathrm{k}))\right|$

\subsection{Fungsi Objektif dan Batasan}

Tujuan penempatan kapasitor adalah untuk mengurangi hilangnya energi dan pengaturan tegangan agar tidak keluar dari batas tegangan yang diperbolehkan dari sistem. Perhitungan Total kehilangan daya diselesaikan dengan output aliran daya melalui persamaan sebagai berikut : 


$$
P_{\text {loss }}=\sum_{i=1}^{n} \sum_{j=1(j<i)}^{n} V_{i} V_{j} Y_{i j} \times \cos \left(\theta_{i}-\theta_{j}-\delta_{i j}\right)
$$

Dengan ini merupakan besar dan fase tegangan pada bus I, dan merupakan besar magnetude dan fase dari saluran antara bus I dan bus J. Sehingga batas tegangan pada tiap -tiap bus dapat dipertimbangkan sebagai berikut :

$V_{\min }=0.95$ pu dan $V_{\max }=1.05$ pu.

Dalam simulasi yang dilakukan ada beberapa asumsi yang dipertimbangkan antara lain :

1. Kapasitor yang digunakan adalah kapasitor tetap.

2. Sistem bekerja pada beban yang seimbang.

\subsection{Algoritma Genetika}

Genetika adalah metode untuk mencari algoritma berdasarkan mekanisme seleksi alam dan genetik. Algoritma Genetika adalah algoritma yang digunakan untuk optimisasi berdasar prinsip pencarian biologi yang simultan berdasar banyak titik dalam space pencarian. [2]

Dalam metode algoritma genetik, ada sekelompok individu (yang disebut populasi) untuk permasalahan dalam hal ini, perhitungan aliran daya dinyatakan dalam bentuk bilangan nyata ( real ), yang membentuk gen-gen kromosom. Populasi terbentuk dari generasi acak dan kemudian dipilih oleh prosedur operasi genetik yang terdiri Seleksi, crossover, mutasi. Hasil mutasi dievaluasi menggunakan fungsi fitness untuk menentukan kromosom mana yang dipilih dengan siklus proses berikutnya sampai mencapai nilai yang diinginkan, menghentikan iterasi nilai tertentu sesuai dengan kriteria berhenti yang ditetapkan sebelumnya (nilai tertentu atau dalam generasi tertentu). 2020].

Proses AG mengikuti aturan berikut: [Zulfahri,

1. Tentukan inisial populasi (biasanya string dibangkitkan acak)

2. Evaluasi seluruh individu (aplikasikan beberapa fungsi atau formula individu)

3. Menyeleksi populasi baru dari populasi awal berdasar nilai fitnes dari individu yang diberikan oleh fungsi evaluasi.

4. Aplikasikan operator genetika seperti mutase dan pindah silang untuk tiap anggota populasi untuk mendapatkan pemecahan baru.

5. Evaluasi individual baru yang terbentuk.

6. Ulangi langkah 3-6 (satu generasi) hingga terminasi kriteria memuaskan (biasanya berbentuk nomor generasi tertentu).

\section{HASIL DAN PEMBAHASAN}

Model saluran ini adalah data dari 30-bus IEEE (Saadat H, 1999). Data tersebut terdiri dari 30 bus dan 24 saluran, slack bus, 4 kontrol tegangan dan 2 pusat pembangkit. Single line diagram untuk sistem 30 bus IEEE dapat dilihat pada Gambar 5.

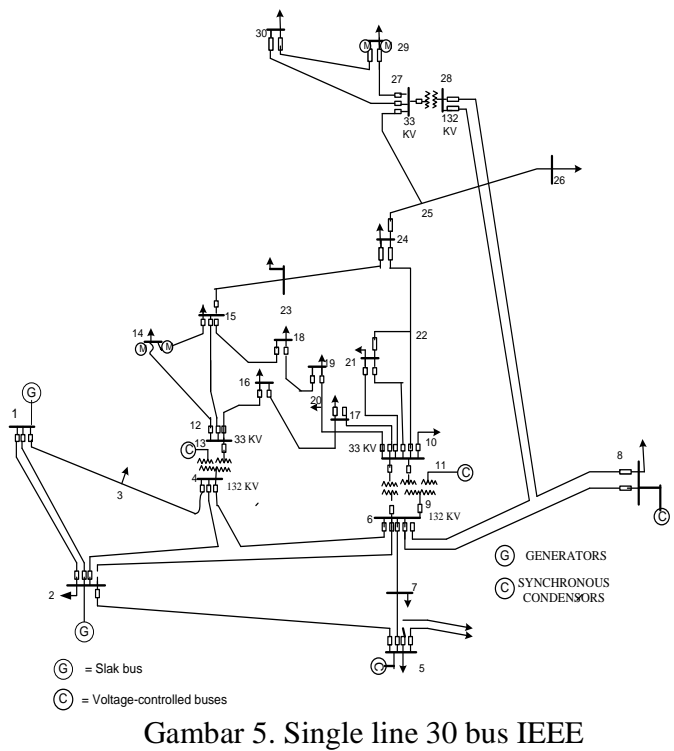

Metode pengolahan data adalah sistem data standar IEEE, yang terdiri 30 bus dan 24 saluran, 1 slack bus, 4 kontrol tegangan dan 2 pusat pembangkit yang diamati melalui aliran daya Newton Rapshon yaitu profil tegangan tiap-tiap bus serta rugi-rugi daya aktif dan reaktif. didapati pada Tabel 1. sebagai berikut :

Tabel 1 Data sistem standar 30 bus IEEE.

Maximum Power Mismatch $=4.93337 \mathrm{e}-08$ No. of Iterations $=10$

\begin{tabular}{|c|c|c|c|c|c|c|c|}
\hline \multirow{2}{*}{$\begin{array}{l}\text { Bus } \\
\text { No }\end{array}$} & \multirow{2}{*}{$\begin{array}{c}\text { Voltage } \\
\text { Mag }\end{array}$} & \multirow{2}{*}{$\begin{array}{c}\text { Angle } \\
\text { Degree }\end{array}$} & \multicolumn{2}{|c|}{ Load } & \multicolumn{2}{|c|}{ Generation } & \multirow{2}{*}{$\begin{array}{l}\text { Injected } \\
\text { Mvar }\end{array}$} \\
\hline & & & MW & Mvar & MW & Mvar & \\
\hline 1 & 1.060 & 0.000 & 0.000 & 0.000 & 266.130 & 89.241 & 0.000 \\
\hline 2 & 1.003 & -5.135 & 21.700 & 12.700 & 40.000 & 38.351 & 0.000 \\
\hline 3 & 0.958 & -7.637 & 2.400 & 21.200 & 0.000 & 0.000 & 0.000 \\
\hline 4 & 0.944 & -9.417 & 7.600 & 11.600 & 0.000 & 0.000 & 0.000 \\
\hline 5 & 0.915 & -14.528 & 94.200 & 19.000 & 0.000 & 0.000 & 0.000 \\
\hline 6 & 0.944 & -11.504 & 0.000 & 30.000 & 0.000 & 0.000 & 0.000 \\
\hline 7 & 0.923 & -13.369 & 22.800 & 10.900 & 0.000 & 0.000 & 0.000 \\
\hline 8 & 0.960 & -12.644 & 30.000 & 30.000 & 0.000 & 84.239 & 0.000 \\
\hline 9 & 0.986 & -15.308 & 0.000 & 5.000 & 0.000 & 0.000 & 0.000 \\
\hline 10 & 0.954 & -17.343 & 5.800 & 2.000 & 0.000 & 0.000 & 19.000 \\
\hline 11 & 1.082 & -15.308 & 0.000 & 0.000 & 0.000 & 49.984 & 0.000 \\
\hline 12 & 0.936 & -15.917 & 11.200 & 7.500 & 0.000 & 0.000 & 0.000 \\
\hline 13 & 0.936 & -15.917 & 0.000 & 0.000 & 0.000 & 0.000 & 0.000 \\
\hline 14 & 0.905 & -16.534 & 6.200 & 8,600 & 0.000 & 0.000 & 0.000 \\
\hline 15 & 0.906 & -16.850 & 8.200 & 2.500 & 0.000 & 0.000 & 0.000 \\
\hline 16 & 0.935 & -16.891 & 3.500 & 1.800 & 0.000 & 0.000 & 0.000 \\
\hline 17 & 0.942 & -17.470 & 9.000 & 5.800 & 0.000 & 0.000 & 0.000 \\
\hline 18 & 0.893 & -17.448 & 3.200 & 10.900 & 0.000 & 0.0 & 0.000 \\
\hline 19 & 0.903 & -18.002 & 9.500 & 3.400 & 0.000 & 0.000 & 0.000 \\
\hline 20 & 0.915 & -17.922 & 2.200 & 17.500 & 0.000 & 0.000 & 0.000 \\
\hline 21 & 0.935 & -17.80 & 17.500 & 12.200 & 0.000 & 0.000 & 0.000 \\
\hline 22 & 0.935 & -17.767 & 0.000 & 0.000 & 0.000 & 0.000 & 0.000 \\
\hline 23 & 0.888 & -17.057 & 3.200 & 11.600 & 0.000 & 0.000 & 0.000 \\
\hline 24 & 0.905 & -17.815 & 8.700 & 6.700 & 0.000 & 0.000 & 4.300 \\
\hline 25 & 0.900 & -17.410 & 0.000 & 0.000 & 0.000 & 0.000 & 0.000 \\
\hline 26 & 0.880 & -17.949 & 3.500 & 2.300 & 0.000 & 0.000 & 0.000 \\
\hline 27 & 0.907 & -16.8 & 0.000 & 0.00 & 0.000 & 0.0 & 0.000 \\
\hline 28 & 0.939 & -12.1 & 0.000 & 4.000 & 0.000 & 0.0 & 0.000 \\
\hline 29 & 0.850 & $\begin{array}{r}17.392 \\
\end{array}$ & 2.400 & 10.900 & 0.000 & 0.000 & 0.000 \\
\hline 30 & 0.854 & -19.114 & 10.600 & 0.900 & 0.000 & 0.000 & 0.000 \\
\hline & & & 283.400 & 232.200 & 306.130 & 261.814 & 23.300 \\
\hline
\end{tabular}

Pada simulasi Optimalisasi pengaturan tegangan di Jaringan Listrik menggunakan Genetik 
Algoritma. Proses pengoptimalan ditujukan untuk meminimalkan ukuran keseluruhan kapasitor shunt yang digunakan dan total kehilangan daya dalam sistem jaringan. Pembatasan yang perlu dipertimbangkan adalah:

1. Batasan tegangan pada bus $\mathrm{Vmin}=0.95 \mathrm{pu}$ dan $\mathrm{V} \max =1.05 \mathrm{pu}$.

2. Ukuran total kapasitor shunt akan dialokasikan maksimum 25 Mvar.

Berikut ini akan menampilkan hasil simulasi dengan Genetika Algoritma dalam pengaturan tegangan di Jaringan Listrik pada 30 bus test system. Profil tegangan pada tiap bus adalah sebagai berikut:

Tabel 2. Perbandingan tegangan sebelum dan sesudah optimalisasi kapasitor shunt.

\begin{tabular}{|c|c|c|c|c|c|c|}
\hline \multirow[b]{2}{*}{ Bus } & \multicolumn{3}{|c|}{ Tegangan sebelum Optimasi } & \multicolumn{3}{|c|}{ Tegangan sesudah Optimasi } \\
\hline & Voltage & Angle & Injected & Voltage & Angle & Injected \\
\hline No & Mag & Degree & Mvar & Mag & Degree & Mvar \\
\hline 1 & 1.060 & 0.000 & 0 & 1.060 & 0.000 & 0 \\
\hline 2 & 1.003 & -5.135 & 0 & 1.013 & -5.135 & 0 \\
\hline 3 & 0.958 & -7.617 & 0 & 0.962 & -7.617 & 0 \\
\hline 4 & 0.944 & -9.417 & 0 & 0.949 & -9.417 & 3.9 \\
\hline 5 & 0.915 & -14.448 & 0 & 0.922 & -14.448 & 0 \\
\hline 6 & 0.944 & -11.380 & 0 & 0.947 & -11.380 & 0 \\
\hline 7 & 0.923 & -13.255 & 0 & 0.928 & -13.255 & 0 \\
\hline 8 & 0.960 & -12.466 & 0 & 0.960 & -12.466 & 0 \\
\hline 9 & 0.986 & -15.055 & 0 & 0.982 & -15.055 & 0 \\
\hline 10 & 0.954 & -17.047 & 19.000 & 0.944 & -17.047 & 0 \\
\hline 11 & 1.082 & -15.055 & 0 & 1.082 & -15.055 & 0 \\
\hline 12 & 0.936 & -15.949 & 0 & 0.944 & -15.949 & 0 \\
\hline 13 & 0.936 & -15.949 & 0 & 0.950 & -15.949 & 4.4 \\
\hline 14 & 0.905 & -16.534 & 0 & 0.912 & -16.534 & 0 \\
\hline 15 & 0.906 & $\begin{array}{l}-16.799 \\
\end{array}$ & 0 & 0.910 & $\begin{array}{r}-16.799 \\
\end{array}$ & 0 \\
\hline 16 & 0.935 & -16.912 & 0 & 0.941 & -16.912 & 4.4 \\
\hline 17 & 0.942 & -17.262 & 0 & 0.942 & -17.262 & ( 0 \\
\hline 18 & 0.893 & -17.306 & 0 & 0.893 & -17.306 & 0 \\
\hline 19 & 0.903 & $\begin{array}{l}-17.811 \\
\end{array}$ & 0 & 0.900 & $\begin{array}{l}-17.811 \\
\end{array}$ & 0 \\
\hline 20 & 0.915 & -17.702 & 0 & 0.910 & -17.702 & 0 \\
\hline 21 & 0.935 & -17.567 & 0 & 0.929 & -17.567 & 2.6 \\
\hline 22 & 0.935 & -17.529 & 0 & 0.928 & -17.529 & 0 \\
\hline 23 & 0.888 & -16.965 & 0 & 0.891 & -16.965 & 0 \\
\hline 24 & 0.905 & -17.670 & 4.3 & 0.904 & -17.670 & 4.3 \\
\hline 25 & 0.900 & -17.325 & 0 & 0.905 & -17.325 & 0 \\
\hline 26 & 0.880 & -17.858 & 0 & 0.885 & -17.858 & 0 \\
\hline 27 & 0.907 & -16.779 & 0 & 0.915 & -16.779 & 2.3 \\
\hline 28 & 0.939 & -12.074 & 0 & 0.942 & -12.074 & 0 \\
\hline 29 & 0.850 & -17.271 & 0 & 0.859 & -17.271 & 0 \\
\hline 30 & 0.854 & -19.021 & 0 & 0.863 & $\begin{array}{l}-19.021 \\
\end{array}$ & 0 \\
\hline & TOTAL & & 23.3 & TOTAL & & 21.9 \\
\hline
\end{tabular}

Grafik tegangan sebelum optimasi penempatan kapasitor memperlihatkan kondisi tegangan pada tiap-tiap bus. Pada bus 1 dan bus 11 mengalami kelebihan tegangan sebesar 1,060 dan 1,082, pada bus 2, 3, 8, 9 dan 10 kondisi normal sedangkan pada bus yang lain mengalami penurunan tegangan. Sedangkan sesudah optimasi penempata kapasitor shunt pada bus 4, 13, 16, 21, 24, 27 dengan penambahan sebesar 21.9 Mvar menghasilkan profil tegangan pada tiap-tiap bus menjadi lebih baik. Gambar 6

Tabel 2. mempresentasikan kondisi awal sistem 30 bus IEEE sebelum optimisasi peletakan peralatan Kapasitor shunt .Berdasarkan tabel tersebut, profil tegangan pada Bus 1 dan 11 keluar dari batasan yang ditentukan. Sedangkan tegangan terendah sebelum optimasi sebesar 0.850 sedangkan setelah optimasi tegangan terendah sebesar 0.859 pada bus ke 29 .

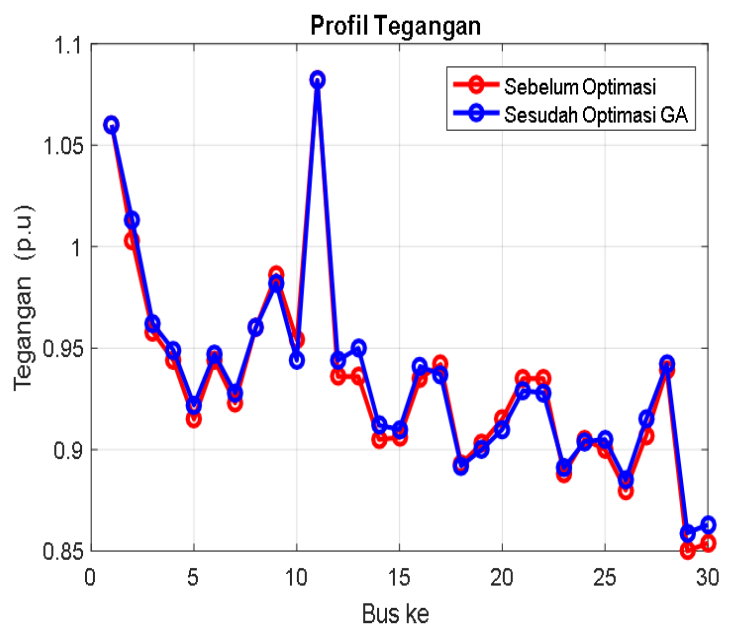

Gambar 6. Grafik tegangan sebelum dan sesudah optimasi

Dari data diatas diperoleh perhitungan total kehilangan daya yaitu total kehilangan daya total diperoleh dari selisih daya pembangkit terhadap daya beban.

Beban)

Rugi-rugi $=($ Daya Pembangkitan- Daya

Rugi-rugi $=($ Daya Pembangkitan- Daya Beban $)$.

$$
\begin{aligned}
& =(306.130-283.400) \mathrm{MW} \\
& =2.73 \mathrm{MVA} \\
& =22730 \mathrm{kVA}
\end{aligned}
$$

Tabel 2 juga merepresentasikan kondisi sistem 30 bus setelah optimisasi penempatan peralatan Kapasitor shunt menggunakan metode yang diusulkan.Hasil simulasi menunjukkan bahwa profil tegangan pada tiap-tiap bus menjadi lebih baik. Perhitungan rugi - rugi total yang diperoleh dari selisih daya pembangkitan dengan daya beban dari hasil optimasi adalah sebagai berikut : Beban).

Rugi-rugi $=$ (Daya Pembangkitan- Daya

$$
\begin{aligned}
& =(305.418-283.400) \mathrm{MW} \\
& =20.018 \mathrm{MVA} \\
& =20018 \mathrm{Kva}
\end{aligned}
$$

Dari persamaan data diatas terlihat pengurangan nilai sebesar $2712 \mathrm{kVA}$, dari nilai sebelum sebelum optimasi sebesar 22730 kVA, setelah optimasi menjadi 20018 kVA. Prosentase penghematan diperoleh :

$$
\begin{aligned}
\% \text { Penghematan } & =\frac{22730-20018}{22730} 100 \% \\
& =11.9313 \%
\end{aligned}
$$

Hal ini memperlihatkan rugi-rugi daya minimum telah diperoleh, dan penghematan daya listrik dapat dilakukan sebesar $11.9313 \%$.

Perhitungan dengan metode Genetika algoritma memperlihatkan nilai loses yang semakin rendah seiring pertambahan iterasi. Hal ini diperlihatkan Gambar 7. memperlihatkan rugi daya aktif dan gambar 8. memperlihatkan rugi daya reaktif. 


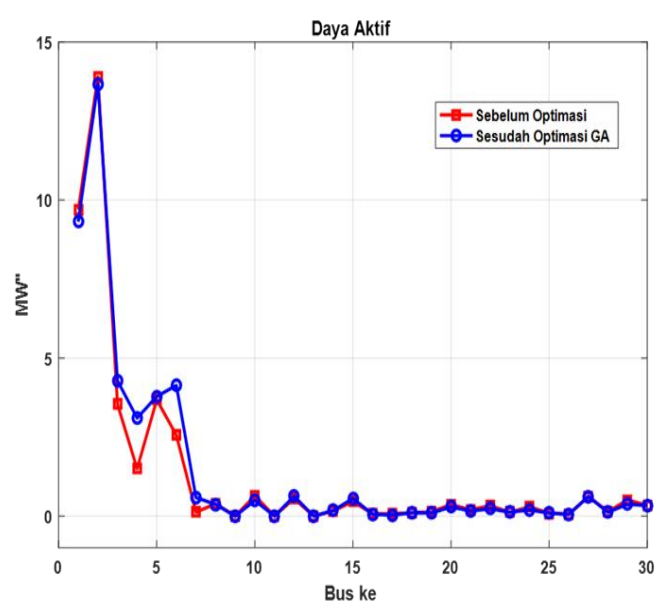

Gambar.7. Perbaikan daya Aktif sebelum dan sesudah optimasi

Setelah optimisasi hanya sedikit yang dapat dikurangi dibandingkan dengan kondisi awal. Tetapi ada suatu penghematan yang cukup signifikan dari ukuran kapasitor yang digunakan setelah proses optimisasi. Ukuran kapasitor total 23.3 Mvar pada kondisi sebelum optimasi dapat dikurangi menjadi 21.9 Mvar, sehingga penghematan kapasitor sebesar 1.4 Mvar.

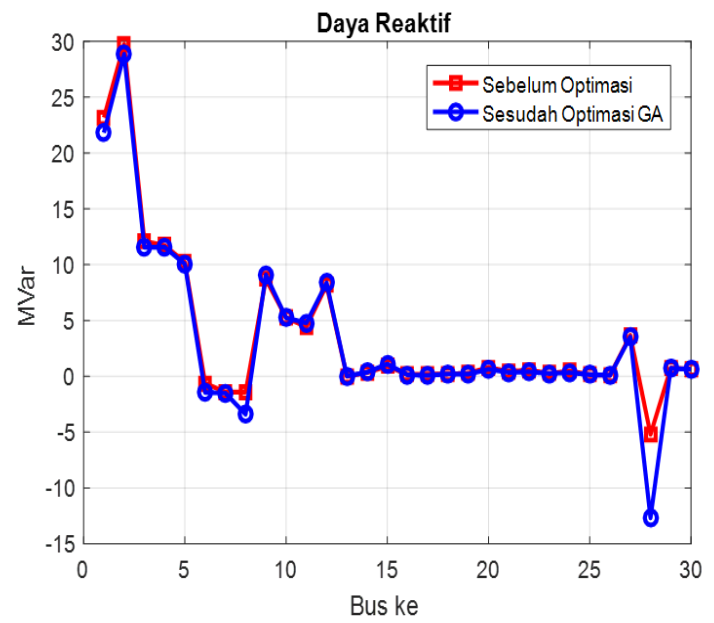

Gambar 8. Perbaikan daya Reaktif sebelum dan sesudah optimasi

\subsection{Analisis}

Dari hasil simulasi yang ditunjukkan pada Gambar 6 dan 8 menunjukkan bahwa :

1. Pengaturan Tegangan yang simulasikan dengan metode genetika algoritma dengan bantuan matlab R16a menempatkan Kapasitor shunt yang optimal untuk mengontrol tegangan sehingga profil tegangan pada tiap bus lebih baik dari sebelum adanya pemasangan kapasitor.

2. Dengan adanya penambahan kapasitor, mengoptimalkan penyaluran daya reaktif pada sistem yang mengalami perubahan akibat tegangan turun dan tegangan lebih, sehingga memenuhi kebutuhan beban.

\section{KESIMPULAN}

Berdasarkan pengamatan dan analisis penelitian pada sistem 30 bus IEEE, Hasil penelitian ini telah didapati beberapa kesimpulan sebagai berikut:

1. Hasil dari komputasi yang diusulkan dalam pengaturan tegangan dengan Genetik algoritma, penempatan Kapasitor sebagai control tegangan dengan penambahan injeksi sebesar 21,9 Mvar pada bus 4, 13, 16, 21, 24, 27 dapat memperbaiki tegangan, sehingga memenuhi kebutuhan daya reaktif.

2. Kinerja komputasi yang dapat dicapai untuk menunjukan peningkatan hasil yang memuaskan. Hal ini dapat dilihat dalam kondisi sebelum optimasi penempatan Kapasitor dengan tegangan terendah pada bus 29 sebesar 0,850 pu sedangkan sesudah optimasi tegangan terendah adalah sebesar 0,859 pu.

3. Pada optimisasi ini hanya sedikit tegangan yang dapat dikurangi dibandingkan dengan kondisi awal. Tetapi ada suatu penghematan yang cukup signifikan dari ukuran kapasitor yang digunakan setelah proses optimisasi. Ukuran kapasitor total 23.3 Mvar pada kondisi sebelum optimasi dapat dikurangi menjadi 21.9 Mvar, sehingga penghematan kapasitor sebesar 1.4 Mvar.

\subsection{Saran}

Saran-saran yang dibutuhkan untuk pengembangan penelitian selanjutnya antara lain:

1. shunt capacitor yang digunakan tidak hanya dari tipe fixed capacitor, tetapi melibatkan tipe-tipe yang lain (seperti switched capacitor) .

2. Penentuan lokasi dan ukuran kapacitor pada sistem dapat dilakukan dengan mempergunakan metode artificial Intelegence yang lain.

\section{DAFTAR PUSTAKA}

[1] Arlenny, Elvira Zondra and Zulfahri, Optimation of Capacitor Bank Placement in Electric Network Using Genetic Algorithm. Journal of Physics: Conference Series. URICSE.2019

[2] Christopher Theophilus Prayogo1, Osea Zebua2, Khairudin Hasan3. Optimasi Kapasitas Bank Kapasitor Untuk Mereduksi Rugi-Rugi Daya Pada Penyulang Wortel Menggunakan Metode Grey Wolf Optimizer (GWO) - Jurnal Rekayasa 
dan Teknologi Elektro. Volume 13, No. 3, September 2019

[3] Saadat H. 1999 Power System Analysis Series in Electrical and Computer Engineering Grainger McGraw-Hill,

[4] Yusmartato, Analisa Peningkatan Stabilitas Stabilitas Tegangan dengan menggunakan Kapasitor .. Buletin Utama Teknik Vol. 13, No. 1, September 2017

[5] Zainal Abidin, Optimalisasi Pengaturan Tegangan dengan Algoritma Genetika. Jurnal Teknika, Volume 1 No.2 Tahun 2009.

[6] Zulfahri, Elvira Zondra, Optimasi Penempatan Peralatan SVC dengan Metode Algoritma Genetika. Jurnal Teknik -Volume 14, Nomor1, Edisi April 2020, Halaman 114-120.

[7] Zulfahri, Abrar Tanjung, Monice, Studi Perbandingan Aliran daya Optimal Mempertimbangkan Economi Dispatch Menggunakan Artificial Immune system Clonal (AIS)-CSA Dengan Algoritma Genetika . Seminar Nasional Pakar ke 3 Tahun 2020. 